\title{
Introduction
}

\section{A New Global in Times of Transition?}

This issue of Global Europe - Basel Papers on Europe in a Global Perspective has been written and designed under the conditions of the COVID regime - the changed appearance of our Basel Papers is therefore more than an editorial coincidence. These special circumstances have delayed publication but they were also an incentive to focus our intellectual attention on processes of transformation well beyond the imprints of the pandemic. Transformation periods are dynamic, fast, confusing, and they rarely evolve from a singular incident, but from a bundle of mutually reinforcing developments at the most diverse levels. Transformation processes raise the questions of why, when and with which social, political and economic consequences changes acquire structural significance, who benefits and who suffers from them. The reading, interpreting and understanding of transformation processes are core interests and competences of the Social Sciences and Humanities (SSH). Encompassing a variety of disciplines, methodologies and conceptual frameworks, SSH do not seek to trade in narrow or mere short-term solutions but offer more substantial insights into options for action in ways that transcend the specific topic addressed.

Another SSH-related specificity to mention is disciplinary self-reflection, which critically examines methods and theories in the light of the changing profiles of the societies analyzed. In the case of the Institute for European Global Studies, the mission statement understands globality as a challenge embedded in asymmetrical power relations and sociopolitical tensions, although without alternatives: "The globalized world of the $21^{\text {st }}$ century is simultaneously shaped by profound dichotomies, multi-faceted entanglements and dis-entanglements. It is a world of reduced distances, more closely connected than ever before through the global mobility of individuals, objects, goods, and ideas. It is also a world that witnesses increasing calls for partition, separation and exclusion. The construction of a strong nation state, defined by alleged linguistic, cultural and religious authenticity, deeply affects ideas of identity. At the same time, processes of globalization have profoundly influenced the construction of identities and forms of democratic decision-making hitherto based on ideas of territorial organization." ${ }^{1}$ And while the mission statement remains useful in the most recent challenge presented by the pandemic, the methodological and disciplinary question how to adapt research designs to shifting concepts is still an unsolved problem engaging and occupying the research community.

1 “Aims and Profile: European Global Studies,” Institute for European Global Studies, accessed June 9, 2021, https://europa.unibas.ch/en/research/aims-and-profile/. 
Have the two main features of the Institute's research approach, the global focus and the interdisciplinary methods, remained stable in the ongoing transformation process? Are they helpful in understanding and steering the world? At first glance, not really: COVID-19 has a territorializing impact, and the limitation of border crossings posed by the health crisis has been reinforced in June 2021 by the decision of the Swiss government to break off negotiations on the institutional framework agreement with the European Union. This development is fed by the idea that there is something so characteristically Swiss that it is indivisible, non-negotiable and inaccessible to pragmatic approaches across borders. Obviously, there is an increasing gap between global health regulations and national containment, a trend to overestimate cultural and political differences, a tendency to overvalue territoriality and locality. It is generally known that globality is a predominant characteristic of today's world, but the presence of the global has shifted from a well-visible program which is at best cosmopolitan and humanitarian to an undercurrent, difficult to grasp, hidden behind diverse labels, although present in everyday life in pragmatic ways.

The latest scientific debates react to this challenge in different ways. Within global history as an interdisciplinary field of historiography, there is an obvious trend to overcome Eurocentric periodizations with transtemporal approaches. ${ }^{2}$ This perspective is often combined with the aim to transcend methodological nationalism by a regional focus. In recent research literature, the new regional is the new global present that shows global influences in their local and sometimes transnational dynamics. ${ }^{3}$ Driven by the question of how SSH can analyze dynamic transformation processes, the greatest challenge is probably not the thematic orientation and the choice of the 'right' topic, but the methodological sea change. The need for a new methodological understanding emerges from a positive development, namely the increasing accessibility of digitized source material. Although indispensable for global history and interdisciplinary cooperation on a global scale, digital humanities are still far from developing into an intrinsic element of SSH methodologies. Under the premise of artificial intelligence and the advancement of machine

2 As examples see Tirthankar Roy and Giorgio Riello, eds., Global Economic History (London et al.: Bloomsbury Academic, 2019); Martti Koskenniemi, To the Uttermost Parts of the Earth: Legal Imagination and International Power 1300 - 1870 (Cambridge/New York: Cambridge University Press, 2021 (forthcoming)); Raphael Schäfer and Anne Peters, eds., Politics and the Histories of International Law: The Quest for Knowledge and Justice, Studies in the History of International Law, vol. 50/18 (Leiden/Boston: Brill/Nijhoff, 2021 (forthcoming)).

3 For the interplay and connectivity of regional, national and international agencies, the most recent as well as the newly announced publications about the League of Nations have a paradigmatic character at least for the history of the 20 ${ }^{\text {th }}$ century: Carolin Liebisch-Gümüs, Verflochtene Nationsbildung: Die Neue Türkei und der Völkerbund 1918-38, Studien zur Internationalen Geschichte, vol. 48 (Berlin/Boston: De Gruyter, 2020); Peter Becker and Natasha Wheatly, eds., Remaking Central Europe: The League of Nations and the Former Habsburg Lands, The History and Theory of International Law Series (Oxford: Oxford University Press, 2020); Harumi Goto-Shibata, The League of Nations and the East Asian Imperial Order, 1920 - 1946, New Directions in East Asian History Series (Singapore: Palgrave Macmillan, 2020). 
learning, new and fascinating forms of modelling are emerging. With that, in the spirit of the above-mentioned disciplinary self-reflection, SSH increasingly require a systematic approach to the question of what is put forward and what is marginalized under these conditions, and to what extent modeling mirrors and patterns tagged facts, materials, events, but misses to extend the empirical evidence required for this purpose. This is especially crucial for periods of transition.

With that in mind, the contributions presented here do not begin with events and objects, but with their oblivion and the specific forms of rediscovery and transformation. In Katekisama Susanna Burghartz has discovered a figure that can almost be understood as a focal point of transcultural misunderstandings. Katekisama is the name of a statue that is actually owned by a Japanese Buddhist monastery and kept as national heritage in the National Museum in Tokyo - but this figure, understood as Japanese national heritage, is none other than Erasmus of Rotterdam, coming to Japan as a ship figure more than 400 years ago, and has shifted, accumulated, and merged identities for centuries. The other two articles in this issue of the Basel Papers deal with the curious stories of objects that should be very hard to miss: massive metal Buddhist bells and Japanese fire bells. And yet, taking up the case of Japanese bells preserved in Swiss collections, the two authors, Hans Bjarne Thomsen and Madeleine Herren, have faced an unexpected problem for their respective disciplinary expertise, East Asian Art History and Global History: big, heavy bronze bells should have been easy to trace on their way from Japan to Swiss collections and their journey should have been easy to document - all the more so as the bells' inscriptions were telling. Their travelling, however, left no paper trail and no documents that allowed to bring the bells preserved in Swiss collections into context with the well-documented history of ethnographic collections. In his contribution, Hans Bjarne Thomsen argues that the original belongings of the bells are unusually well documented, with dates, places, contexts cast into the bell itself, sometimes mentioning the temple where they were placed. He explains that, in terms of the original Japanese documentation, these objects function within spaces that are very different from oblivion - in terms of documentation in texts and inscriptions, but also in terms of being visibly and audibly part of the community and belonging to the temple. They had a real presence, which then was stripped from them in their move to Switzerland - and into oblivion. Madeleine Herren locates the globality of the bells outside their respective religious and cultural functions, and assumes that the materiality of the bells had a transformative and globalizing impact. This approach leads to the result that their recognition as a work of art was literally overwritten with the rules of a worldwide commodity trade under which the bells became part of a global scrap metal market. In both cases, the statue of Erasmus and the bells from Japan, the objects' respective function has been fundamentally reinterpreted and transformed 
over the course of history, leaving imprints and patterns in which their respective role as global icons of transformation becomes visible only under the condition that they are brought to speak outside their original context and outside the rules and norms of their respective origin. 